\title{
Pengaruh Fortifikasi Nugget Moringa Oleifera Terhadap Peningkatan Kadar Hemoglobin
}

\section{Effect of Moringa Oleifera Nugget Fortification on Increasing Hemoglobin Levels}

\author{
Azizatul Hamidiyah ${ }^{1}$, Dewi Andariya Ningsih, Lia Fitria \\ Prodi DIII Kebidanan Fakultas Ilmu Kesehatan, Universitas Ibrahimy \\ 1Email: azizatulhamidiyah@ibrahimy.ac.id
}

\begin{abstract}
ABSTRAK
Anemia merupakan masalah kesehatan yang banyak terjadi terutama di negara berkembang. Remaja putri memiliki risiko anemia sepuluh kali lebih besar dibandingkan dengan remaja putra. Santri memiliki prevalensi anemia yang lebih tinggi dibanding remaja putri pada umumnya. Salah satu upaya yang dapat dilakukan dalam penangulangan anemia adalah dengan fortifikasi. Oleh karena itu, tujuan penelitian ini adalah untuk mengetahui pengaruh fortifikasi nugget Moringa Oleifera terhadap peningkatan kadar hemoglobin. Metode penelitian ini menggunakan true experimen design. Sampel dalam penelitian ini berjumlah 30 dengan teknik simple random sampling dengan kriteria inklusi. Instrumen penelitian ini menggunakan lembar observasi dan recall gizi serta set HB Check digital merk Quick Check. Analisis penelitian ini menggunakan uji univariat dan bivariat dengan uji repeated measure anova. Hasil penelitian menunjukkan tidak ada pengaruh fortifikasi nugget Moringa Oleifera terhadap peningkatan kadar hemoglobin dengan Pvalue 0,234 > 0,05.
\end{abstract}

Kata Kunci: Fortifikasi, Nugget Moringa Oleifera, Kadar Hemoglobin

ABSTRACT

Anemia is a health problem that often occurs, especially in developing countries. Young women have a ten times greater risk of anemia compared to young men. Santri has a higher prevalence of anemia than teenage girls in general. One effort that can be done in the treatment of anemia is fortification. Therefore, the purpose of this study was to determine the effect of Moringa Oleifera nugget fortification on increasing hemoglobin levels. This research method used true experimental design. The sample in this study amounted to 30 with simple random sampling technique. The instrument of this study used nutritional observation and recall sheets and the digital HB Check brand Quick Check. The analysis of this study used a univariate and bivariate test with repeated measure anova test. The results showed no effect of Moringa Oleifera nugget fortification on increasing hemoglobin levels with a P value of 0.234> 0.05 .

Keywords $\quad$ : Fortification, Moringa Oleifera Nugget, Hemoglobin Levels

\section{PENDAHULUAN}

Anemia merupakan masalah

kesehatan yang banyak terjadi terutama di negara berkembang. Remaja putri memiliki risiko anemia sepuluh kali lebih besar dibandingkan dengan remaja putra. Remaja putri mengalami peningkatan kebutuhan besi karena percepatan growth spurt dan menstruasi (Lych, 2000). Anemia pada remaja dapat menyebabkan keterlambatan pertumbuhan fisik, gangguan perilaku, emosional. Bila keadaan akut, keadaan anemia dapat menyebabkan kematian. Anemia yang terjadi pada remaja putri juga merupakan risiko terjadinya 
gangguan fungsi fisik dan mental, serta dapat meningkatkan risiko terjadinya gangguan pada saat kehamilan nantinya (Sediaoetomo, 1992). Menurut Yip (1998) status besi harus diperbaiki pada saat sebelum hamil yaitu sejak remaja sehingga keadaan anemia pada saat kehamilan dapat dikurangi.

$$
\text { Menurut WHO }
$$

prevalensi anemia dunia berkisar 40$88 \%$. Berdasarkan data hasil Riskesdas tahun 2013, prevalensi anemia di Indonesia yaitu $21,7 \%$ penderita anemia berumur 15-24 tahun sebesar 18,4\% (Kemenkes RI, 2013). Survey yang dilakukan kepada siswa sekolah di Indonesia menunjukkan prevalensi anemia sebesar 36\%-43\% (Astuti \& Rosidi, 2011).

Hasil penelitian yang dilakukan oleh Hamidiyah (2018) menunjukkan bahwa 111 dari 140 (79\%) santri putri asrama pusat Pondok Pesantren Salafiyah Syafi'iyah Sukorejo mengalami anemia. Begitu pula berdasarkan hasil penelitian yang dilakukan oleh Soan (2018) menunjukkan bahwa 87 dari 90 (97\%) mahasiswa Kebidanan Universitas Ibrahimy mengalami anemia.

Secara umum tingginya prevalensi anemia di Indonesia disebabkan defisiensi besi dan mineral lainnya, seperti vitamin A, C, folat, riboplafin dan B12 (Briawan, 2014). Hasil penelitian Andasari (2017) menunjukkan bahwa ada hubungan signifikan antara asupan nutrisi dengan terjadinya anemia pada remaja puteri dengan Pvalue 0,038. Begitu pula hasil penelitian yang dilakukan oleh Hamidiyah (2018) menunjukkan bahwa semakin tinggi asupan nutrisi maka 3,01 kali semakin rendah pula santri terkena anemia.

Produk olahan yang saat ini cukup popular di kalangan masyarakat yaitu nugget. Olahan nugget disukai di segala usia termasuk remaja. Namun, kandungan nugget yang ada dirasa kurang sehat karena proporsi kandungannya yang kurang bernutrisi. Selain itu, tidak semua nugget dapat dipastikan keamanan pangannya. Sehingga perlu dilakukan pengembangan produk nugget, penelitian ini mencoba melakukan dengan fortifikasi serbuk kelor (Moringa Oleifera). Sayuran kelor semua bagian pohonnya dapat dimanfaatkan. Hasil penelitian While Gopalan, el al. (2010) menunjukkan bahwa seluruh bagian tanaman kelor bermanfaat bagi kesehatan. Begitu pula Bey (2010) 
menunjukkan kandungan $\mathrm{Fe}$ serbuk kelor 25 kali lipat lebih tinggi dibanding sayuran bayam, vitamin A 10 kali lipat lebih tinggi dibanding dengan wortel. Dan 7 kali lebih tinggi kandungan Vitamin $\mathrm{C}$ dibanding dengan jeruk. Sebagaimana yang diketahui $\mathrm{Fe}$ merupakan mineral yang sangat berpengaruh dalam pembentukan hemoglobin. Sedangkan vitamin A berperan dalam memobilisasi cadangan besi dalam tubuh untuk dapat mensintesis $\mathrm{Hb}$. Dan vitamin $\mathrm{C}$ berperan dalam meningkatkan abrsopsi zat besi. Dengan adanya nugget kelor ini diharapakan sebagai upaya untuk membudayakan mengkonsumsi makanan yang menyehatkan dan untuk membuat produk makanan yang mempunyai inovasi baru dan disukai seluruh kalangan masyarakat. Nugget kelor juga sebagai solusi bagi remaja yang tidak suka sayur, karena kelor telah diekstrak dalam olahan nugget.

Oleh karena itu, penting dilakukan penelitian olahan makanan baru, unik sekaligus sehat berupa nugget kelor. Tujuan penelitian ini yaitu untuk mengetahui pengaruh fortifikasi nugget Moringa Oleifera terhadap peningkatan kadar hemoglobin dalam upaya penanggulangan anemia remaja putri di
Pondok Pesantren Salafiyah Syafi'iyah Sukorejo Situbondo Tahun 2019.

\section{METODE PENELITIAN}

Penelitian ini merupakan penelitian kuantitatif dengan desain True Eksperimen . Lokasi penelitian dilakukan di Pondok Pesantren Salafiyah Syafi'iyah Sukorejo Situbondo. Waktu penelitian dilakukan selama 10 bulan pada Tahun 2019. Populasi dalam penelitian ini adalah remaja putri di Pondok Pesantren Salafiyah Syafi'iyah Sukorejo Situbondo. Sampel dalam penelitian ini yaitu 30 remaja putri dengan menggunakan rumus :

$$
n=\frac{4 \bullet \sigma^{2} \bullet\left(z_{\alpha}+z_{\beta}\right)^{2}}{\left(\mu_{1}-\mu_{2}\right)^{2}}
$$

Pengambilan sampel menggunakan teknik simple random sampling . Kriteria inklusi sampel penelitian ini sebagai berikut:

a. Berusia 18-21 Tahun

b. Telah mengalami menstruasi

c. Tidak memiliki gangguan tidur, dan tidur minimal 4 jam

d. Tidak sedang menstruasi saat penelitian

e. Tidak dalam keadaan puasa selama penelitian 
f. Bersedia menjadi responden dan kadar $\mathrm{Hb}$ menggunakan uji penelitian dan mentaati segala repeated measure Anova. aturannya

Pengumpulan data dilakukan dengan uji perbedaan kadar $\mathrm{Hb}$ kepada 30 remaja putri yang anemia sebelum dan sesudah mengkonsumsi nugget yang difortifikasi 2\% serbuk Moringa Oleifera mengacu pada hasil penelitian organoleptik sebelumnya (Hamidiyah, dkk., 2019)

Tabel 1 Komposisi Formula Nugget

\begin{tabular}{llr}
\hline No. & \multicolumn{1}{c}{ Bahan } & $\begin{array}{c}\text { T2 } \\
(\mathbf{2 \%})\end{array}$ \\
\hline 1 & Daging Ayam $(\mathrm{g})$ & 250 \\
2 & Serbuk Kelor $(\mathrm{g})$ & 5 \\
3 & Roti (Lembar) & 6 \\
4 & dll & 1 \\
\hline \multicolumn{3}{c}{ Instrumen dalam } \\
\end{tabular}

yaitu lembar observasi hasil pengamatan kadar hemoglobin dan lembar observasi recall gizi dan aktivitas fisik untuk mengontrol bias, dan set alat Hemoglobin Test merk Quick Check, darah responden, alcohol swab, blood lancet.

Analisis data dilakukan menggunakan uji univariat dan bivariat. Uji univariat untuk mengetahui gambaran kadar $\mathrm{Hb}$ responden sebelum dan sesudah intervensi selama 1x24 jam, 3x24 jam dan $7 \times 24$ jam. Uji Bivariat dilakukan untuk mengetahui pengaruh fortifikasi nugget kelor terhadap organoleptik

\section{HASIL DAN PEMBAHASAN}

Sebelum dilakukan uji repeated measure anova dilakukan uji normalitas dan test of varians terlebih dahulu. Uji kenormalan dilakukan karena uji repeated measure anova merupakan uji statistik parametrik, sehingga nilai standarized residual harus berdistribusi normal. Hasil uji normalitas dan test of varians sebagaimana Tabel 2 dan 3.

Tabel 2. Uji Normalitas Standarized Residual

Keterangan Sig

\begin{tabular}{lc}
\hline Standarized Residual for Awal & 0.06 \\
Standarized Residual for $1 \times 24$ jam & 0,200 \\
Standarized Residual for $3 \times 24$ jam & 0,200 \\
Standarized Residual for 7x24 jam & 0,200 \\
\hline
\end{tabular}

Tabel 3. Uji Varians

Keterangan

Sig

\begin{tabular}{ll}
\hline Waktu & 0.431 \\
\hline
\end{tabular}

$$
\text { Berdasarkan Tabel } 2
$$

menunjukkan bahwa data standarized residual berdistribusi normal dengan nilai Pvalue > 0,05. Dan Data juga memiliki varians yang sama dengan Pvalue $>0,05$. 
Sedangkan hasil uji repeated dalam Tabel 4. measure anova ditunjukkan sebagaimana

Tabel 4. Uji Pengaruh Fortifikasi Nuggget Moringa Oleifera Berdasarkan Waktu Dengan Peningkatan Kadar Hemoglobin

\begin{tabular}{|c|c|c|c|c|c|c|}
\hline \multicolumn{2}{|c|}{ Source } & \multirow{2}{*}{$\begin{array}{r}\begin{array}{c}\text { Type III } \\
\text { Sum of } \\
\text { Squares }\end{array} \\
7.761\end{array}$} & \multirow{2}{*}{$\begin{array}{r}\text { df } \\
3\end{array}$} & \multirow{2}{*}{$\begin{array}{l}\begin{array}{c}\text { Mean } \\
\text { Square }\end{array} \\
2.587\end{array}$} & \multirow{2}{*}{$\begin{array}{l}\mathbf{F} \\
1.464\end{array}$} & \multirow{2}{*}{$\begin{array}{l}\text { Sig. } \\
.230\end{array}$} \\
\hline waktu & $\begin{array}{l}\text { Sphericity } \\
\text { Assumed }\end{array}$ & & & & & \\
\hline \multirow{7}{*}{ Error(waktu) } & $\begin{array}{l}\text { Greenhouse- } \\
\text { Geisser }\end{array}$ & 7.761 & 2.657 & 2.921 & 1.464 & .234 \\
\hline & Huynh-Feldt & 7.761 & 2.950 & 2.631 & 1.464 & .231 \\
\hline & Lower-bound & 7.761 & 1.000 & 7.761 & 1.464 & .236 \\
\hline & $\begin{array}{l}\text { Sphericity } \\
\text { Assumed }\end{array}$ & 153.749 & 87 & 1.767 & & \\
\hline & $\begin{array}{l}\text { Greenhouse- } \\
\text { Geisser }\end{array}$ & 153.749 & 77.054 & 1.995 & & \\
\hline & Huynh-Feldt & 153.749 & 85.549 & 1.797 & & \\
\hline & Lower-bound & 153.749 & 29.000 & 5.302 & & \\
\hline
\end{tabular}

Tabel 5. Rata-Rata Peningkatan Kadar Hemoglobin Berdasarkan Waktu

\begin{tabular}{|c|c|c|c|c|c|c|}
\hline \multirow{2}{*}{ (I) Waktu } & \multirow{2}{*}{ (J) Waktu } & \multirow{2}{*}{$\begin{array}{c}\text { Mean } \\
\text { Difference } \\
(\mathbf{I}-J)\end{array}$} & \multirow{2}{*}{$\begin{array}{l}\text { Std. } \\
\text { Error }\end{array}$} & \multirow{2}{*}{ Sig. ${ }^{a}$} & \multicolumn{2}{|c|}{$\begin{array}{c}95 \% \text { Confidence } \\
\text { Interval for Difference }\end{array}$} \\
\hline & & & & & $\begin{array}{l}\text { Lower } \\
\text { Bound }\end{array}$ & $\begin{array}{l}\text { Upper } \\
\text { Bound }\end{array}$ \\
\hline \multirow[t]{3}{*}{1} & 2 & .067 & .333 & 1.000 & -.876 & 1.010 \\
\hline & 3 & .460 & .418 & 1.000 & -.725 & 1.645 \\
\hline & 4 & .600 & .348 & .571 & -.385 & 1.585 \\
\hline \multirow[t]{3}{*}{2} & 1 & -.067 & .333 & 1.000 & -1.010 & .876 \\
\hline & 3 & .393 & .333 & 1.000 & -.551 & 1.338 \\
\hline & 4 & .533 & .303 & .535 & -.325 & 1.392 \\
\hline \multirow[t]{3}{*}{3} & 1 & -.460 & .418 & 1.000 & -1.645 & .725 \\
\hline & 2 & -.393 & .333 & 1.000 & -1.338 & .551 \\
\hline & 4 & .140 & .311 & 1.000 & -.741 & 1.021 \\
\hline \multirow[t]{3}{*}{4} & 1 & -.600 & .348 & .571 & -1.585 & .385 \\
\hline & 2 & -.533 & .303 & .535 & -1.392 & .325 \\
\hline & 3 & -.140 & .311 & 1.000 & -1.021 & .741 \\
\hline
\end{tabular}

Berdasarkan Tabel $4 \quad 0,05$ sehingga $\quad \mathrm{H}_{0}$ diterima artinya menunjukkan bahwa nilai Greenhouse- tidak ada pengaruh intervensi fortifikasi Geisser menunjukkan pvalue 0,234 > nugget Moringa Oleifera terhadap kadar 
hemoglobin pada kurun waktu tertentu yaitu perbandingan kadar hemoglobin awal, 1x24 jam, 3x24 jam dan 7x24 jam.

Sedangkan berdasarkan Tabel 5 peningkatan kadar hemoglobin berdasarkan kurun waktu dari pre (awal), 1x24 jam, 3x24 jam dan 7x24 jam menujukkan bahwa rata-rata kadar hemoglobin awal dibandingkan dengan rata-rata kadar hemoglobin $1 \times 24$ jam sebesar 0,067 tetapi perbedaan rata-rata tersebut tidak nyata dengan Pvalue 1,000. Begitu pula pada rata-rata kadar hemoglobin awal dibandingkan dengan rata-rata kadar hemoglobin $3 \times 24$ dan 7 x24 jam sebesar 0,460 dan 0,600 dengan perbedaan rata-rata tersebut tidak nyata dengan Pvalue 1,000 dan 0,571.

Sehingga dapat disimpulkan bahwa dengan rutin mengkonsumsi nugget fortifikasi berdasarkan nilai mean memang menunjukkan peningkatan kadar Hemoglobin, tetapi belum terbukti nyata karena peningkatan kadar hemoglobin tidak cukup signifikan. Sehingga berdasarkan nilai pvalue > 0,05 yang menunjukkan tidak ada perbedaan yang signifikan rata-rata kadar hemoglobin setelah diberi intervensi nugget Moringa Oleifera dengan kurun waktu tertentu.

Hemoglobin adalah protein yang terdiri dari empat rantai polipeptida yang masing-masing mengandung heme yaitu pigmen porphyrin merah yang di dalamnya terkandung ion besi yang berfungsi untuk mengangkut oksigen.

Sebagaimana yang diketahui pula bahwa daya absorbsi Fe Hem 10-30 \% dan Non Hem sebesar 2-10\%. Sedangkan makanan yang bercampur dengan putih telur (Protein Albumin) maka akan mempengaruhi penurunan daya abrsorb Fe sebesar $40 \%$.

Nugget kelor terdiri dari campuran Fe Hem dan Non Hem. Non Hem berupa sumber nabati yaitu serbuk kelor dan Hem berasal dari hewani yaitu daging ayam dan putih telur sebagai pelumur nugget sebelum diberi tepung panir.

Daging ayam merupakan sumber protein yang berkualitas tinggi dan mengandung vitamin B kompleks, sumber asam lemak yang baik dan asam amino esensial serta merupakan sumber mineral yang lengkap. Selain itu seratserat dagingnya empuk, mudah dikunyah dan dicerna serta mempunyai potensi rasa yang khas yang secara umum disukai. Manfaat daging ayam bagi kesehatan sangat tinggi, karena selain berserat, mengandung asam amino essensial yang lengkap dan dalam 
perbandingan jumlah yang baik juga merupakan bahan makanan yang mengandung protein tinggi, serta vitamin dan mineral (Dharmayanti dalam Widyatiningrum,dkk, 2018).

Secara teori daya absorb protein hewani umumnya meningkatkan penyerapan Fe Non Hem, tetapi protein albumin pada putih telur sangat berperan besar hingga $40 \%$ dalam mempengaruhi absorb $\mathrm{Fe}$.

Sehingga dibutuhkan strategi lanjutan dalam upaya peningkatan kadar hemoglobin melalui substitusi putih telur dengan bahan lain untuk memaksimalkan absorbsi. Dan atau dengan memperlama waktu intervensi, mengingat adanya peningkatan kadar hemoglobin linier dengan bertambahnya kurun waktu intervensi. Sebagaimana penelitian terdahulu dalam melakukan intervensi kadar hemoglobin ada yang 1x24 jam, 3-7x24 jam, hingga 90 hari.

\section{SIMPULAN DAN SARAN}

Simpulan penelitian ini menunjukkan bahwa tidak ada pengaruh fortifikasi nugget Moringa Oleifera terhadap peningkatan kadar hemoglobin pada kurun waktu 1x24, 3x24 dan 7x24 jam. Saran penelitian ini adalah melakukan intervensi dengan menambah interval kurun waktu intervensi, karena apabila dianalisis hasil mean kadar hemoglobin menunjukkan peningkatan linier dengan lama waktu intervensi. Selai itu dapat juga dengan mensubstitusi putih telur dengan bahan lain dalam pembuatan nugget Moringa Oleifera.

\section{DAFTAR PUSTAKA}

Allen, L., dkk., 2006. Guideline on Food Fortification with Micronutriens. Jenewa:WHO

Astuti, R., \& Rosidi, A. 2014. Kadar Hemoglobin Pada Siswi Pondok Pesantren Putri Kecamatan Mranggen Kabupaten Demak Jawa Tengah. Universitas Muhammadiyah Semarang: Prosiding Seminar Nasional \& Internasional.

Bey. 2010. All Things Moringa.

Briawan, D. 2012. Anemia Masalah Gizi pada Remaja Wanita. Jakarta: EGC

Fellows, P. 1990. Food Processing Technologi :Principal and Practice. New York: Elis Harwood.

Gopalan, C. 2010. Nutrition Research in Southeast Asia. New Delhi, WHO

Hamidiyah, A., \& Hikmah, R. 2018. Penanggulangan Anemia melalui Kader Kokoa Moringa Oleifera (Komo). Journal of Community Engagement in Health, 1(2), 1-5.

Hamidiyah, A., \& Hikmah, R. 2018. PELATIHAN PEMBUATAN CAMILAN SEHAT KOKOAMORINGA OLEIFERA (KOMO) DESA SUMBEREJO DAN SUMBERANYAR. Conference on Innovation and 
Application of Science and Technology (CIASTECH), 1(1), 195-203

Hamidiyah, A., 2018. Composition of Chicken Liver Nugget to Organoleptic and Hemoglobin Levels in the Efforts to Prevent Adolescent Female Anemia. International Conference on Sustainable Health Promotion, 114-118.

http://proceedings.uinsby.ac.id/in dex.php/ICOSHPRO/article/view 125

Hamidiyah, A., Rohmani, L., Zahro, N.A. 2019. Faktor Determinan Anemia Santri Putri. Oksitosin : Jurnal Ilmiah Kebidanan. Vol.6 (1). P:64-72. Diakses dari https://journal.ibrahimy.ac.id/ind ex.php/oksitosin/article/view/345

Hamidiyah, A., Ningsih, D.A., Fitria, L. 2019. Pengaruh Fortifikasi Kelor terhadap Organoleptik Nugget. Conference on Innovation and Application of Science and Technology (CIASTECH).
Kementrian Kesehatan RI. 2013. Riset Kesehatan Dasar Nasional. Jakarta: Kementrian Kesehatan RI

Krisnadi. 2013. Kelor Super Nutrisi. Blora: Pusat Informasi dan Pengembangan Tanaman Kelor Indonesia.

Krisnadi, A. D. 2012. Kelor Super Nutrisi. Retrieved Mei 1, 2019, from kelorina.com

Prayitno,N. 2015. Nutritional Relationship.

Soan, Y.A. 2018. Hubungan Status Gizi dan Aktivitas Fisik dengan Kejadian Anemia Mahasiswa Universitas Ibrahimy. KTI. Situbondo: Universitas Ibrahimy.

Widyawatiningrum, E., Nur, S. and Ida, N.C., 2018. Kadar Protein dan Organoleptik Nugget Ayam Fortifikasi Daun Kelor ( Moringa Oleifer a Lamk ). Seminar Nasional Hasil Penelitian dan Pengabdian Masyarakat. pp.200-205. 